\title{
THE PAST AND THE PROSPECT OF ADMINISTRATIVE DIVISION OF GEORGIA
}

\begin{abstract}
Historically speaking, Georgia never had an opportunity to independently determine the form of country's administrative division. Due to some factors, including foreign and domestic policies, and socio-economic conditions, it was inevitable to divide the country into certain territorial units; however, Georgia has never been a strictly centralized state. The presented paper discusses the issue of administrative division in legal documents created in independent Georgia. The issue is debated with reference to the first Constitution of the Democratic Republic of Georgia adopted in 1995, and the second amended Constitution adopted in 2004, and the third amended constitution adopted in 2010. The paper also reviews all the amendments of the Georgian Constitution introduced in the past 20 years, which have not brought any significant changes on the issue of administrative division. The author analyses what may be the best administrative division for Georgia by considering two existing regional conflicts, and underlines the positive and negative aspects of Federalism and Unitarism.
\end{abstract}

Key words: Administrative Division of State, Federalism, Autonomous Republics.

\section{Introduction}

The administrative division of a country represents a system of political and legal relations between the central government and the governments of the territorial entities. According to the so-called "Doctrine of Three Elements", the organization of its authority on certain territory is the necessary precondition for the existence of each country (Gonashvili et al., 2017:149). The form of the administrative division expresses the vertical organization of the government.

*marijiqia@gmail.com 
Constitutions of different countries define the form of administrative division, but there are almost no states with the unitary form of administrative division, which have declared this type of administrative division in the constitution; yet, each state has relevant legal provisions, on the basis of which it is easy to determine it.

Unlike the unitary states, in the federal states, legal provisions on the administrative division may be found not only in their constitutions but also in the name of the country (e.g. the Federal Republic of Germany, the Russian Federation, etc.).

In the course of its long-standing history, Georgia has rarely been able to independently determine the form of administrative division of the country (Margishvili, 2016: 198). Taking into consideration foreign and domestic policies, economic conditions and other factors, it was necessary to divide the country into certain territorial units; however, Georgia has never been a strictly centralized state (Tsaava, 2012: 175).

This paper will discuss the issue of administrative division in the legal documents created in the history of independent Georgia. This issue has been unresolved for years, and has been further complicated by the existence of conflict regions.

\section{A historical overview of the administrative division issue}

\subsection{The issue of administrative division in the period 1918-1921}

After the restoration of Georgian independence in the early $20^{\text {th }}$ century, the administrative division issue was put on the national agenda along with various other issues. In the period 1918-1921, the Democratic Republic of Georgia was a unitary decentralized state with several autonomous territories. .

The idea of federalism was opposed by the National-democrats for their own political convictions and by the Federal-socialists who, although supporting the idea of federalism, believed that the federal structure of the state could be injurious unless the State gained strength (Tsaava, 2012:178), which could have been caused by the historical-cultural, economic-political situation and other circumstances (Gegenava, 2018:305).

In the first republic, all political forces were favoring the idea that the existence of territorial units with special status was inevitable (Gegenava, 2019:305). According to the opinions of the majority of members of the Constitutional Commission, granting the autonomous status to some territories would only be justified if the ethnic minorities had settled the territory and, at the same time, if there were an economic basis. For this reason, the initial decision included 
only the autonomy of Abkhazia, but ultimately the autonomy was granted to Abkhazia, Adjara and Zakatala.

The Constitution of Georgia of 1921, as noted above, did not stipulate the federal administrative division, but it determined the broad cultural autonomy of national minorities and protection of their rights (Margishvili, 2016:204). Chapter $\mathrm{XI}$ of the Constitution, which covered the issue of administrative division, consisted of two Articles:

According to Article 107, the integral parts of the territory of Georgia: Abkhazia (Sokhumi district), Samuslimo (Muslim) Georgia (Batumi region), and Zakatala were granted "autonomous governance in local affairs" (Constitution of Georgia, 1921, Article 107);

According to Article 108, autonomous entities autonomous entities were entitled to enact their own legal provisions, which had to be adopted in compliance with the law.

The rest of the country was divided into administrative units, governed by the local self-governments, but they had to abide by the instruction of the central authorities in the management and administration issues.

\subsection{The issue of administrative division in the early $1990 \mathrm{~s}$}

In the aftermath of the 70-year long annexation and gaining independence, as a result of the first multi-party elections in 1990, the national forces under the leadership of Zviad Gamsakhurdia came to power. During the early 1990s, many institutional changes were implemented, including the issue of administrative division, in particular by introducing the system of prefectures and local assemblies. At that time, the Council of People's Delegates of the Autonomous District of South Ossetia declared the "Soviet Republic of South Ossetia", which applied to the Soviet Union for unification and becoming a constituent part of it. For this reason, on $11^{\text {th }}$ December 1990, the Supreme Council of the Republic of Georgia adopted the Law on the "Abolition of the South Ossetian Autonomous District" (Rukhadze, 1999:206). Given the emerging threat of having the South Ossetia's request approved by the Kremlin, Georgia abolished the autonomous district and its governing bodies (Malashkhia, 2011:144).

The State Trustee Institute was created before the adoption of the Constitution of 1995. The regions and towns of Georgia were merged and reorganized into nine regions, whereby the majority of new administrative boundaries coincided with the boundaries of historical areas (Gegenava, 2019:307). 


\subsection{The issue of administrative division in the first version of the Constitution of 1995}

The Constitution adopted in 1995 does not foresee the form of the administrative organization of the state. This was again caused by two conflict regions. At the moment of enacting the higher law of the country, there were two autonomous republics, a former autonomous district, and nine administrative-territorial units existing in Georgia (Melkadze, Tevdorashvili, 2003:200). The absence of a precise status in the constitution led to the possibility of various interpretations; namely, under Article 1 (paragraph 1) of the Constitution, "Georgia is an independent, unified and indivisible state". According to some scholars and practicing lawyers, this provision implies the unitary administrative division of the country. For some constitutionalists, a sign of federalism was the constitutional provision according to which bicameral parliament was envisaged after the restoration of territorial integrity.

The legislator connects the introduction of the bicameral parliamentary system with "the creation of the appropriate conditions in the whole territory of Georgia and forming local self-government" (Constitution of Georgia (24/08/1995), Article 4(1)). The upper chamber (the Senate) is composed of representatives from the following territorial units: Autonomous Republic of Abkhazia, Autonomous Republic of Adjara and other territorial units of Georgia (Constitution of Georgia (24/08/1995), Article 4 (3)). This means that, "after the creation of the relevant conditions", other territorial units will be created in Georgia in addition to the Autonomous Republics of Adjara and Abkhazia. It indicates that the legislator plans to create at least a decentralized and at most a federal administrative division in the future (Gegenava et al., 2013: 148). It is true that one of the features of the federal state is the existence of a bicameral parliamentary system, although the provision in the Constitution of Georgia on the "unity and integrity" contradicts the idea of federalism. Therefore, after the creation of "appropriate conditions", the legislator is likely to prefer a regional or decentralized unitary State (Gegenava et al., 2013: 148). Such a constitutional provision may be interpreted differently; namely, it may be construed that the state has no form of administrative division before the restoration of its territorial jurisdiction, which is impossible (Gegenava, 2018: 308).

The initial version of the Constitution, including the autonomous status of Abkhazia and Adjara, was also provided indistinctly; they are mentioned in the Constitution only with given names and, under Articles 67 and 89, they had higher legislative, executive and judicial authorities.

According to the amendment introduced in the Constitution of Georgia in 2000, the name of Adjara was defined by the words "Autonomous Republic of Adjara"; 
a similar change was made in relation to Abkhazia in 2002, but the difference between them was that the Parliament of Georgia adopted the Constitutional Act in 2004 to determine the status of the Autonomous Republic of Adjara while a similar act on Abkhazia has never been adopted (Gegenava, 2018: 308).

It is noteworthy that the Supreme Courts of the Autonomous Republics were functional until 2005, as they were part of a unified system of common courts. Yet, in 2005, they were transformed into the Courts of Appeal and later on they were abolished (Gegenava, 2018: 309).

The Constitutional Act adopted in 2008 established the body of the state trustee - the "governor". The governor's function was to conduct state supervision on the activities of the local self-government bodies. This provision was amended later and the governor was placed under the direct subordination of the government.

\section{The administrative division of Georgia under the amended and consolidated version of the Constitution}

As a result of the constitutional reform of 2017-2018, no qualitative changes have been made in terms of administrative division. Some terms were corrected, but the main provisions remained unchanged. According to Article 7 of the Constitution, concerning the administrative division, "The powers of the Autonomous Republic of Abkhazia and the Autonomous Republic of Adjara and the procedures for exercising such powers shall be determined by the constitutional laws of Georgia that are an integral part of the Constitution of Georgia" (Constitution of Georgia (24/08/1995), Article 7 (2)). The Constitution has already defined their status as autonomous republics; as for their frames of autonomy and rights, they are defined by the constitutional law.

As a result of recent changes, the autonomous republics gained additional authority, which is connected with the election of the President of Georgia, in particular the Electoral Board, including the Members of Parliament and delegates of the representative bodies of local self-government, as well as all members of the higher representative bodies of the Autonomous Republics of Abkhazia and Adjara (Constitution of Georgia (24/08/1995), Article 50 (3)).

One of the major changes in the administrative division is that, after the restoration of jurisdiction over the entire territory of the country, the administrative division of Georgia will be revised by a constitutional act (Constitution of Georgia (24/08/1995), Article 7 (3)).The previous version noted that the issue of administrative division was defined. The term "revision" is more appropriate because it is about the change of the model. 
According to the new (amended) version of the Constitution, acting upon the proposal of the Government and the consent of the Parliament, the President of Georgia has the authority to suspend the activities of the representative body of a territorial unit or to dissolve it, if its actions threaten the sovereignty, territorial integrity, implementation of constitutional powers of state authorities (Constitution of Georgia (24/08/1995), Article 50 (2)).

\subsection{The Autonomous Republic of Abkhazia}

In 1918, Abkhazia was part of the Democratic Republic of Georgia. The issue of its autonomy was put on the agenda as soon as the independence was declared. On $11^{\text {th }}$ June 1918, a treaty was signed between the Democratic Republic of Georgia and the Abkhazian People's Council, according to which the Minister of the Abkhazian Affairs was being appointed by the Government of Georgia upon being nominated by the Abkhazian Council. Governance was carried out by the Abkhazian People's Council and funded by the Government of Georgia (Malashkhia, 2011, 78).

On $13^{\text {th }}$ February 1919, the Abkhazian People's Council (elected as a result of the first democratic elections) adopted the Act on the "Autonomy of Abkhazia". Under Article 107 of the Constitution of 1921, Abkhazia (Sokhumi Region), as an integral part of the Democratic Republic of Georgia, was granted local autonomous governance (Gegenava, 2018: 313).

According to the current legislation, Abkhazia has a status of a special autonomous republic, which is underlined by the designation that the official languages in Abkhazia shall be Georgian and Abkhazian (Constitution of Georgia (24/08/1995), Article 2 (3)).

The Supreme Representative Authority of the Autonomous Republic of Abkhazia has the right of legislative initiative in the Parliament of Georgia (Constitution of Georgia (24/08/1995), Article 45). Abkhazia is also represented in the presidential Election Board and, in the future, it will have a number of seats in the Senate, but the number has not yet been defined.

\subsection{The Autonomous Republic of Adjara}

Under the Constitution of the Democratic Republic of 1921, the Batumi area was declared an integral part of Georgia, which was granted autonomy along with the Sokhumi and Zakatala districts. On $13^{\text {th }}$ October 1921, the Agreement of Kars was signed, which transferred the historic territories of Georgia to Turkey, and Turkey gave Georgia the city of Batumi only on the condition that the local 
population would benefit from broader autonomy and that their cultural and religious rights would be protected (Gegenava, 2018: 321).

In 1921, Adjara was granted the status of the autonomous Soviet Socialist Republic, which had not changed until the restoration of independence. At the time of the restoration independence of Georgia, the Constitution of 1978 was operating in Georgia, under which Adjara had the status of the autonomous republic, its own constitution, and the three branches of government.

As noted above, in accordance with the amendment introduced into the Constitution of 1995 in 2000, the name of Adjara was defined by the words "the Autonomous Republic of Adjara" and, in 2004, the Parliament adopted the Constitutional Act "On the Status of the Autonomous Republic of Adjara". As the legislation of the Autonomous Republic of Adjara was completely dropped out from the constitutional order of Georgia, some changes were necessary. This was followed by the adoption of the 2004 constitutional law on the status, initially determining the issues of the governance of the Autonomous Republic of Adjara, the structure and functions of the Higher Authorities of the Autonomous Republic of Adjara (Gegenava, 2018: 323). This was followed by the adoption of the new Constitution of the Autonomous Republic of Adjara in 2017.

The constitutional reform of 2017-2018 led to the adoption of a new constitutional law on the Autonomous Republic of Adjara, which comprises five Articles (Constitutional Act of Georgia on the Autonomous Republic of Adjara (13/10/2017)).

The norms of the Constitutional Act of Georgia on the "Autonomous Republic of Adjara" are almost completely repeated in the Act on "Direct State Governance in the Autonomous Republic". The amendments to the Constitutional Act on Adjara have been made at different times, but the amendment made in 2018 completely undermines the conceptual framework of the Constitutional Act. The very first sentence of this Act specifies that the basis for adopting this law was the Constitutional Act of Georgia on the Autonomous Republic of Adjara and not the Constitution, i.e. that it is only about the Autonomous Republic of Adjara. In this case, the necessity of enacting this Act is unclear because the Constitutional Act already regulates the same issue (Gegenava, 2018: 325)

\subsection{The temporary administrative-territorial unit established on the territory of the former South Ossetian Autonomous District}

In 2007, the Parliament of Georgia adopted the Act on the creation of appropriate conditions for Peaceful Settlement of the Conflict in the Former South Ossetian Autonomous District, aimed at the implementation of provisional state gover- 
nance on the territory of the former South Ossetian Autonomous District, before the full restoration of the territorial jurisdiction of Georgia. By the decree of the President of Georgia, the provisional administrative-territorial unit envisaged by the law was created in the same year.

The administration of the temporary administrative-territorial unit was created for the implementation of state governance. Administration is a state governing body financed from the state budget of Georgia (Demetrashvili, Kobakhidze, 2011: 131). The main powers of the administration include: execution of the state governance under the delegated authority; conducting negotiations on the autonomous status of the former South Ossetian Autonomous District; cooperation with state authorities of Georgia within its competences and undertaking relevant measures with the purpose of peaceful resolution of the conflict with international organizations; elaboration of relevant plans and projects for the settlement of conflicts; ensuring involvement of the local community in the course of their preparation process, etc.

Since the war of August 2008, Russian occupational troops have effective control over this territory. Consequently, the administration continues functioning in exile (Demetrashvili, Kobakhidze, 2011: 131).

\section{Some opinions regarding the administrative division of Georgia}

There are frequent discussions in the scientific community which form of administrative division would be relevant for Georgia. The views are divided. There are different variations of federalism: Georgian-Abkhazian dual federation and asymmetric federation.

In 2001, Dieter Boden, Special Representative of the UN Secretary-General in Georgia, elaborated the plan of the Abkhazian conflict settlement titled "The Principles on the Distribution of Competences between Tbilisi and Sokhumi", generally known as the "Boden Document". It comprises 8 points, mainly concerning Russia and Western countries rather than the parties involved in the conflict (Coppieters, 2005: 207).

According to the Boden Document, Georgia is a sovereign state which comprises a sovereign entity - Abkhazia, which has a special status; the relations between Sokhumi and Tbilisi are regulated by the federal constitutional agreement, which has the force of the constitutional law of Georgia that can be altered or revoked by mutual agreement; the distribution of competences between Tbilisi and Abkhazia is based on the federal agreement (Constitutional Law); the Constitutions of Georgia and Abkhazia shall equally protect the fundamental human rights and the rights of national minorities; the Constitution of Abkhazia 
shall include guarantees for the protection of the right of internally displaced persons (IDPs) to return to their places of residence; the issue of joint composition of the Constitutional Court shall be determined in the Constitutions (the Boden Document, 2001: 1-2). Considering the content of the Boden Document, it provides for the double, bipolar and contractual federalism, within which Abkhazia will have special powers.

In 2004, a special concept document on the "special status of Abkhazia in the Republic of Georgia" was developed by Georgian experts. ${ }^{1}$ According to this document, the concept of future administrative division of Georgia should be based on the principles of decentralization. Unlike Classical Federalism, this concept is a specific model adopted as a result of combination of federalism and regionalism, where the status of territorial units should be given to the regions of Georgia, and the special status for Abkhazia should be defined. Under this concept, Abkhazia is a sovereign state unit that acts as an equal partner in relations with the higher government. Abkhazia is a member of the federal republic of Georgia and not its part (the Concept Document, 2004: 9).

According to the Concept Document, a certain number of persons of Abkhaz nationality will sit in the Senate of the Parliament of Georgia, and Abkhazian representatives will have a special, decisive vote on the issues related to Abkhazia (the Concept Document, 2004: 17). The document also provides for other types of guarantees, such as: high quorum system in the Parliament of Abkhazia; restriction of real estate for a certain period of time; guarantees connected with the national currency, etc.

Significant arguments of the federalists supporting the implementation of this model may be summarized as follows:

- In federalism, the spheres of state governance are reasonably divided between the center and the federation bodies;

- Federalism is the best way to resolve ethnic conflicts;

- Federalism is the best way to fight against dictatorship and totalitarianism;

- Federalism is a crucial institution of peace keeping.

\section{Conclusion}

The main part of this article presents various opinions on the positive side of federalism, including some scholar and experts' opinion that federalism is the only way for the restoration of the territorial integrity of Georgia.

1 The group included Konstantine Kublashvili, Archil Gegeshidze, Ivliane Khaindrava, and Paata Zakareishvili. 
As a counterpoint to the above considerations, the author would like to indicate the problems that might be caused by the formation of the federal republic of Georgia:

In the federal republic, it is easier to make decisions oriented to satisfying the local demands. Local problems are closer and more familiar to the politicians, and their resolution may be easier. This particular argument can be annulled by the fact that more responsibilities are to be given to municipalities to resolve local problems; thus, creating federal units is not necessary for this purpose. Increasing the authority certainly means the increase in funding and self-governance, which in turn make their functioning more efficient.

Federalism is characterized by polycentrism, which implies an equal opportunity to develop political processes throughout the entire territory of the country. Political forces with different ideologies have to cooperate with each other and respect each other's positions, which ultimately contributes to developing the culture of political dialogue. This process in a post-Soviet state, such as Georgia, may entail negative practices and effects, expressed in the establishment of a bureaucratic system. The latter makes the work of political institutions more difficult. Untimely establishment of political decision-making process for Georgia, which is at the initial stage of development and democratic values, can be deplorable.

One of the important problems is the problem of controlling the local elite (Khubua, 2000a: 53). To support this argument, we can recall the leadership of the Autonomous Republic of Adjara until May 2004, which in some cases adopted normative acts contrary to the Constitution of Georgia. The wrong policy pursued by the leadership in federal entities can cause the weakness of the country as a whole and the strengthening of federal subjects, which may undermine the idea of unity and integrity. A similar policy contains a special threat in the countries where territorial boundaries of federal subjects coincide with ethnic and linguistic boundaries (Khubua, 2000b:132-153).

One of the important aspects of Federalism is finances. Maintaining a federal state is a great luxury. In the given situation, expenses can be so great that they threaten the economic development of the country. Therefore, proper management of finances is one of the main reasons for successful policy implementation. Federalism is the basis for stability only in economically developed countries (Vedenski, Gorokhov, 2002: 21).

Due to all the aforesaid, the feasibility of federalism is under question in Georgian reality. The two concepts that have been created on the Abkhazian issue do not say anything about regions, such as the former South Ossetia. At the same time, it should be noted that the degree of independence of federal subjects in 
less developed countries would not be a means of taking effective political decisions; it can actually become a threat as it may promote separatist tendencies. Furthermore, the fact is that the level of stability of the federal state in similar countries cannot be high. Whereas any generalization of opinions on this issue would be quite inadequate, all previous considerations are absolutely relevant, particularly in the context of historical developments and Georgia's current reality.

\section{References}

\section{Books, Manuals, Articles}

Gegenava D. (ed.), (2018): Introduction to Constitutional Law of Georgia, Publishing house of Prince David Institute of Law, Sulkhan-Saba Orbeliani University, Tbilisi.

Gegenava D., Kantaria B., Tsanava L., Tevzadze T., Macharadze Z., Javakhishvili P., Erkvani T., Papashvili T. (2013): Constitutional Law of Georgia, Publishing house of Prince David Institute of Law, Tbilisi.

Gonashvili V., Eremadze K., Tevdorashvili G., Kakhiani G., Kverenchkhiladze G., Chigladze N. (2017): Introduction to Constitutional Law, Publishing House "Meridiani", Tbilisi.

Demetrashvili A., Kobakhidze I. (2011): Constitutional Law, Publishing House "Inovatsia", Tbilisi.

Malashkhia Sh. (2011): Autonomy of Conflicts, Publishing House "Forma", Tbilisi.

Margishvili L. (2016): Federalism, as a form of territorial organization historically existing in Georgia, in: Legal Journal of the Faculty of Law, Ivane Javakhishvili Tbilisi State University, Tbilisi.

Melkadze O., Tevdorashvili G. (2003): Regionalism - Form of State Territorial Organization, Publishing house "Spynx", Tbilisi

Rukhadze Z. (1999): Constitutional Law of Georgia, Georgian Young Lawyers Association, Batumi.

Tsaava L. (2012): Past and Perspective of administrative division of Georgia, in: Journal of Law of David Batonishvili Institute of Law, Tbilisi.

Khubua G. (2000 a): Federalism as a normative principle and political order, Georgian Young Lawyers Association, Tbilisi. 
Khubua G. (2000 b): Federated Georgia? Prospects of Federalism of Georgia: PRO ET CONTRA, Collection of Conference Materials, Georgian Young Lawyers Association, Tbilisi.

Vvedensky V. G., Gorokhov A. Yu. (2002): Russia: Tested by Federalism. Theory and practice of domestic and foreign experience, Moscow.

Koppieters, B. (2005): The Georgian-Abkhaz Conflict, in: Europeanization and Conflict Resolution: case studies of the European periphery (Collection of articles), "Ves Mir" Publishing House, Moscow

\section{Legal documents}

The Constitution of Georgia (1921), available at https://www.constcourt.ge/ ge/publications/books/1921-wlis-saqartvelos-demokratiuli-respublikis-konstitucia.page

The Constitution of Georgia (24/08/1995), available at https://matsne.gov.ge/ document/view/30346? publication=35

The Constitutional Act of Georgia on Autonomous Republic of Adjara (13/10/2017), available at https://matsne.gov.ge/document/view/3811829?publication=0

The Boden Document (2001): The Principles for Division of Competences between Tbilisi and Sukhumi1 (Boden Document) March, 2002, GEO-PEACE DATABASE, Peace Agreements, International Center on Conflict and Negotiation, available at http://www.iccn.ge/files/boden__document_2002.pdf

The Concept Document (2004): Concept on the Special Status of Abkhazia in the State of Georgia (Project), Tbilisi (2004); published in the Newspaper 24 Hours ( $30^{\text {th }}$ June 2004); available at http://www.iccn.ge/files/concept_abkhazia_in_georgia_state_2004_eng.pdf 


\section{Др Мириам Јикиа,}

Ванредни професор,

Факултет права и међународих односа,

Грузијски технички универзитет, Тбилиси, Грузија

\section{ПРОШЛОСТ И ПЕРСПЕКТИВЕ АДМИНИСТРАТИВНЕ ПОДЕЛЕ ГРУЗИЈЕ}

\section{Резиме}

Историјски гледано, Грузија никада није била у прилици да самостално утврди облик административне поделе земље. Услед дејства неких фактора, попут спољне и унутрашње политике, и друштвено-економских околности, подела земље на одређене територијалне јединице је неизбежна. Међутим, Грузија никада није била строго централизована држава. Уставом Грузије из 1921 године Абхазија, Аиара и Закатала су добиле аутономију. Након 70-годишње анексије и стищања независности 1990. године, на власт су путем вишестраначких избора дошле националне снаге. Почетком 1990-их уведене су многе институционалне промене, које су обухватиле и питање административне поделе. Као резултат недавних измена Устава Грузије (2017), аутономне републике добиле су додатна овлашћења. Једна од главних новина је да с́е, након врас́ања надлежности над целокупном територијом земље, административна подела Грузије бити ревидирана уставним законом.

У раду се разматра проблем административне поделе у Грузији на основу правних аката који су донети након стицања независности, као и најбоља опщија административне поделе у околностима постојес́хх регионалних сукоба, и подвлаче позитивни и негативни аспекти федерализма и унитаризма. Централни део рада представља разна мишљења о предностима федерализма, као и мишљење неких научника и стручњака да је федерализам једини начин за обнову територијалног интегритета Грузије. Ипак, у реалним околностима, одрживост концепта федерализма је под знаком питања. Два конщептуална документа која се односе на статус Абхазије не помињу статус аутономних области, као што је бивша Јужна Осетија. Истовремено, треба напоменути да степен независности федералних актера у мање развијеним земљама не би био средство за доношење делотворних политичких одлука, већ заправо може представљати претњу и промоцију сепаратистичких тенденција. Томе треба додати чињеницу да ниво стабилности савезне државе у сличним земљама није висок. Дакле, свака генерализација мишљења или ставова по овом питању била би неадекватна.

Кључне речи: административна подела државе, федерализам, аутономне републике. 
